\title{
Odol Tanta Lehorraren fidagarritasunaren azterketa farmakoen analisi kuantitatiborako UHPLC-PDA-FLDren bidez
}

\author{
Study of the reliability of Dry Blood Spot for the quantification \\ of drugs by UHPLC-PDA-FLD
}

Beatriz Uribe, Oskar Gonzalez*, Rosa M. Alonso

Kimika Analitikoa Saila, Zientzia eta Teknologia Fakultatea, UPV/EHU.

* oskar.gonzalezm@ehu.eus

DOI: $10.1387 /$ ekaia.15547

Laburpena: Lan honetan Odol Tanta Lehorraren (OTLa) laginketa-teknikaren fidagarritasuna ikertu da farmakoen analisirako fotodiodo- eta fluoreszentzia-detektagailuei akoplatutako bereizmen oso altuko likido-kromatografiaren (UHPLC-PDA-FLD) bidez. OTLak, odol-tanta bat kotoi-paperezko euskarri batean jartzean eta lehortzen uztean datzan teknikak, azken urteotan erabileraren handipen garrantzitsua antzeman du bioanalisian. OTLak ohiko odol-analisiekiko hainbat abantaila erakutsi arren, analisi kuantitatiboaren ikuspuntutik hainbat faktorerekiko mendekotasuna duela antzeman da. Ikerketa honetan faktore batzuek (hematokritoa, odol-bolumena eta laginketa-puntua) farmakoen determinazioan duten eragina aztertu da, horretarako amilorida, propranolola eta valsartan farmakoak eredu gisa erabiliz. Emaitzetan oinarrituta, zuloaren kokapenak eta hematokritoak analisien zehaztasunean eta doitasunean eragina dutela ondorioztatu da, teknika honen aplikazio kuantitatiboa mugatuz. Bestalde, analitoen sakabanaketa odol-tantan zehar analitoen propietate fisiko-kimikoen mendekoa dela ikusi da, metodo analitikoaren garapenean analito bakoitzaren sakabanaketa aztertu behar dela ondorioztatuz.

Hitz gakoak: Odol Tanta Lehorra, Bioanalisia, UHPLC-PDA-FLD.

\begin{abstract}
In this work, the reliability of Dried Blood Spot (DBS) as a sampling technique for drug analysis was studied by Ultra High Performance Liquid Chromatography coupled to Photodiode-Array and Fluorescence Detection (UHPLC-PDA-FLD). DBS microsampling, a technique based on placing a drop of blood in a cotton support that is allowed to air dry, has lately noticed an increase in use in bioanalysis. Even though it offers several advantages compared to common blood sampling methods, it also shows some limitations for quantitative analysis due to the dependence on different factors. In this study, the influ-
\end{abstract}


ence of some of them (hematocrit, blood volume and sampling position) has been investigated, using amiloride, propranolol and valsartan drugs as model compounds. According to the results, it has been concluded that the sampling position and the hematocrit have influence in the accuracy and precision of the quantitative results, therefore limiting the use of this technique for quantitative analysis. On the other hand, dispersion of the analytes in the blood drop depends on their physicochemical properties which implies that the distribution of each analyte must be carefully studied during method development.

Keywords: DBS, Bioanalysis, UHPLC-PDA-FLD.

\section{SARRERA}

Odol Tanta Lehorraren (OTLa), ingelesez Dried Blood Spot (DBS), laginketa-teknika 1963. urtean erabili zuen lehenengo aldiz giza odolarekin Robert Gurthrie-k. Bere ikerketa-lanetan OTLa jaioberrietan arazo metabolikoak detektatzeko erabili zuen. Hortik aurrera OTLa hainbat arlotan erabili ohi da, hala nola toxikozinetika- eta farmakozinetika-ikerketetan, farmakoen monitorizazioan, gaixotasunen diagnostikoan eta kirol-lehiaketetako dopin-analisietan $[1,2]$. Teknika instrumentalen sentikortasun hobekuntzarekin batera, azken urteotan laginketa-teknika horren erabilera nabarmenki hedatu da eskaintzen dituen abantailak direla medio.

OTLaren laginketa-teknika odol-tanta bat kotoi-paperezko euskarri batean ipintzean oinarritzen da, lehortuko dena eta gero analisirako erabiliko dena. Euskarri hau \% 100 kotoiaz egin ohi da eta bakterioen eta beste mikroorganismo batzuen hazkundea ekiditeko trataturik dago [3]. Hiru odol-tanta dituen OTLan erabilitako euskarri baten argazkia 1. irudian ikus daiteke.

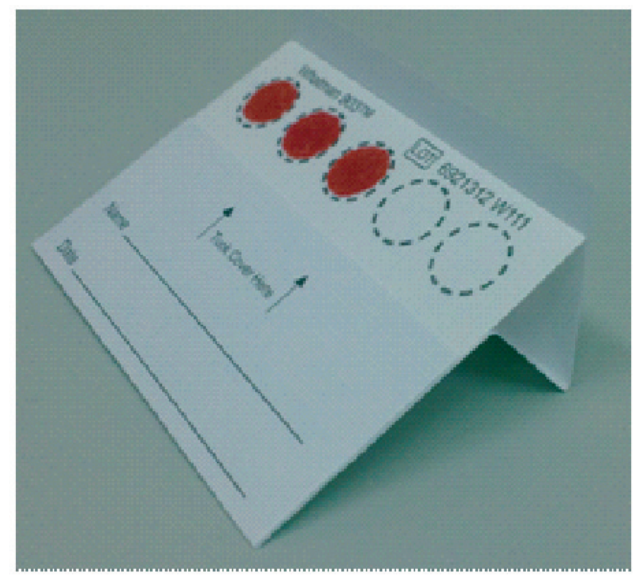

1. irudia. OTLan erabilitako kotoi-paperezko euskarria hiru odol-tantekin. 
Odol Tanta Lehorraren fidagarritasunaren azterketa farmakoen analisi kuantitatiborako UHPLC-PDA-FLDren bidez

OTLaren bidezko prozedura oso erraza da. Nahikoa da gorputzeko edozein tokitan ziztatu eta lortutako odol-tanta paperean jartzea; tokirik erabilienak atzamar bat, belarria eta orpoa dira [2,4]. Matrize horretan dauden konposatuak analizatzeko, normalean disolbatzaile likido baten bidezko erauzketa gauzatzen da, lehortutako odol-tantan zulo bat eginez (ingelesez «punch» terminoa erabiltzen da) eta disoluzioan murgilduz [3]. Erauzketa egiteko, analitoen izaeraren araberako disoluzioa erabiliko da; orokorrean erabilienetariko disolbatzaileen artean metanola, ura eta azetonitriloa daude [5-10]. Erauzketa hau egin ondoren, disoluzioa aukeratutako instrumentuan analizatuko da. Horretarako, hainbat teknika erabiltzen dira gaur egun, haien artean, DNAn oinarritutako entseguak, aktibitate entzimatikoenak, inmunoentseguak, masa-espektrometria (MS) zuzena eta likido-kromatografia detektagailu ezberdinekin akoplatuta [1]. OTLak hainbat abantaila erakusten ditu ohiko odolaren, plasmaren eta serumaren lagin-bilketa metodoekin konparatuta [6]. Abantaila horien artean analitoen egonkortasuna (hezetasunaren eliminazioa eta degradazio entzimatiko ezagatik), beharrezko odol-bolumen txikia eta laginen prozesatzea automatizatzeko aukera daude [11]. Gainera, biltegiratzeko eta garraiatzeko orduan leku gutxi okupatzen dute, orokorrean odol-laginak biltegiratzeko erabiltzen diren odoltutuen aldean [4]. Arrisku biologikoa ere txikiagoa da ohiko odol-lagin likidoekin konparatuta; horren ondorioz, GIB/Hiesa eta beste patogenoekin infektatzeko aukera asko murrizten da. Teknika hau, aipatutako abantailak direla eta, ospitaletan jaioberriei odola hartzeko eta 3. munduan laginketateknika bezala erabili ohi da [2].

Aurreko abantaila garrantzitsu horiek izan arren, teknika honek desabantailak ere baditu. Alde batetik garrantzitsua da partikulen atxikipen, homogeneotasun eta absortzio berdintsuak bermatzea euskarri ezberdinetan zehar [3, 12]. Bestetik, aipatutako zuloaren bidezko analisi kuantitatiboa aurrera eraman nahi bada, analitoen banaketa homogeneoa gertatu behar da odol-tantan zehar, edozein puntutan zuloa hartuta ere beti analitoen kontzentrazio berdina egoteko. Horren ondorioz, analitoen banaketak faktore batzuekiko duen mendekotasuna kontuan hartu behar da, besteak beste odol mota (zainetakoa edo kapilarra) [13, 14], euskarri mota [10, 15], hematokritoa (odolaren dentsitatearekin lotuta) [3, 13, 14, 16-18] eta odoltantaren bolumena $[19,20]$.

Ikerketa-lan honen helburua lagin-bolumenak, hematokritoak eta analisirako hartutako zuloaren kokapenak OTLaren bidezko analisi kuantitatiboan duten eragina aztertzea izan da, teknika horren fidagarritasuna hobetzeko eta euskarrian analitoek duten dispertsioa hobeto ulertzeko. Horretarako, ezaugarri fisiko-kimiko ezberdinak (polaritatea eta azido-base izaera) dituzten hiru farmako (amilorida, propranolol eta valsartan) erabili dira eredu gisa. Gainera, konposatu horien analisia ahalbidetzen duen prozedura analitikoa garatu da eta aukeratu den analisi metodoa fotodiodo- eta 
fluoreszenztia-detektagailuei akoplatutako oso bereizmen altuko likidokromatografia (UHPLC-PDA-FLD) izan da.

\section{OTL-aren BIDEZKO FARMAKOEN ANALISIA}

\subsection{Erreaktiboak}

Amilorida klorhidratoa Sigma-Aldrich (San Luis, Estatu Batuak) etxe komertzialetik lortu da, propranolol klorhidratoa Fluka-tik (Buchs, Suitza) eta valsartana Novartis Pharma AG-tik (Basel, Suitza). Farmakoen lanerako disoluzioak eta disoluzio estandarrak Romil (Cambridge, Ingalaterra) etxe komertzialeko gradiente kalitateko metanolean prestatu dira. pH ezberdinetako disoluzioak prestatzeko dipotasio hidrato fosfatoa (>\% 99), azido azetikoa (LC-MS kalitatea), sodio dihidrato zitrato anhidroa (>\% 99) eta disodio hidrogeno zitrato seskihidratatua ( $>\%$ 99) Fluka etxe komertzialetik lortu dira. Potasio dihidrogeno fosfatoa, sodio azetatoa, trisodio zitrato dihidratatua, amoniakoa (\% 25) eta amonio kloruroa, horiek guztiak Pro-Analysi kalitatezkoak, eta sodio hidroxidoa, EMSURE® Millipore's premium grade) mailakoa, Merck (Darmstad, Alemania) etxeak hornitu ditu. Panreac (Bartzelona, Espainia) etxearen eskutik, azido fosforikoa (\% 85) eta azido zitrikoa (PA-ACS-ISO) erreaktiboak lortu dira. Fase mugikorrak prestatzeko Romil-eko gradiente kalitateko azetonitriloa eta Fluka-ko LC-MS kalitateko azido formikoa erabili dira. Erabilitako ur ultrapurua Millipore (Milford, Estatu Batuak) Milli-Q Element A10-eko sistemakoa izan da.

\subsection{Erabilitako tresnak}

OTLa laginketa aurrera eramateko euskarriak Whatman (Sanford, USA) etxeko «903 Protein Saver Card»-ak izan dira. Erabilitako sistema kromatografikoa Waters-eko (Milford, MA, USA) Acquity UPLCa izan $\mathrm{da}$, fotodiodo (PDA) eta fluoreszentzia (FLD) detektagailuetara akoplaturik, eta zutabe kromatografikoa, berriz, etxe bereko Acquity BEH C18 $(2,1 \times 50,1,7 \mu \mathrm{m})$ izan da. Zutabearen aurretik iragazki bat erabili da partikuletatik babesteko. Sistema kromatografikoaren kontrola eta datuen prozesatzea Empower 2 software-arekin egin da.

Odol-tanten zuloak egiteko, 5,9 mm-ko diametroa duen paper-zulagailu bat erabili da. Analitoen dispertsioaren ikerketan, ordea, 1,2 mm-ko diametroa duen Harris-eko (Micro-punch) zulagailua erabili da gune periferikoa eta zentrala analizatzeko. Analitoen egitura irudikatzeko eta banaketa-koefizientea kalkulatzeko, MarvinSketch 14.9.15 programa erabili da. Odol-tanten azalera neurtzeko, AutoCAD 2016 programa erabili da. Esperimentuen emaitzak tratatzeko, Microsoft Excel 2010 eta Unscrambler 9.7 programak erabili dira. 


\subsection{Disoluzio estandarrak eta odol-laginak}

Farmako bakoitzaren gatzaren $1.000 \mathrm{mg} / \mathrm{L}-\mathrm{ko}$ disoluzioak prestatu dira lehen aipatutako erreaktiboen beharrezko kantitatea metanolean disolbatuz. Horretaz gain, amilorida, propranolol eta valsartan farmakoen $50 \mathrm{mg} / \mathrm{L}-\mathrm{ko}$ disoluzioa prestatu da metanolean, lanerako disoluzioa lez.

Erabilitako odol-laginak Basurtuko Unibertsitate Ospitaleko (Bilbo, Espainia) hematologiako zerbitzutik lortu dira ikerketa klinikoaren etika batzordearen aginduak jarraituz. Zehazki, hematokritoen balio ezberdina (\% 22tik \% 55era) duten 15 laginez hornitu gaituzte, lagin horiek hozkailuan, $-80{ }^{\circ} \mathrm{C}$-ra kontserbatu dira ikerketa osoan zehar, hezetasunetik babesteko. Lanerako erabili den odol guztia $1 \mathrm{mg} / \mathrm{L}$-eko kontzentrazioarekin dopatu da lanerako disoluzio estandarretik abiatuta.

\subsection{Analitoak}

Azterketa aurrera eramateko, propietate fisiko-kimiko ezberdinak dituzten farmakoak erabili dira ahalik eta konposatu gehienen eredu izatea izan baita helburua. Aukeratutako farmakoak amilorida, propranolola eta valsartana izan dira. Horien egitura kimikoa eta hainbat propietate 1. taulan ikus daitezke.

1. taula. Amilorida, propranolola eta valsartana. Horien egitura kimikoak, formula molekularrak, pisu molekularrak eta fluoreszentziako kitzikapenen eta igorpenen uhin-luzerak.

\begin{tabular}{c|c|c|c}
\hline Izena & Amilorida & Propranolola \\
\hline Egitura kimikoa & $\mathrm{C}_{6} \mathrm{H}_{8} \mathrm{ClN}_{7} \mathrm{O}$ & $\mathrm{C}_{16} \mathrm{H}_{21} \mathrm{NO}_{2}$ & $\mathrm{C}_{24} \mathrm{H}_{29} \mathrm{~N}_{5} \mathrm{O}_{3}$ \\
\hline $\begin{array}{c}\text { Formula } \\
\text { molekularra }\end{array}$ & 229,62 & 259,34 & 435,51 \\
\hline $\begin{array}{c}\text { Pisu molekularra } \\
\text { (g/mol) }\end{array}$ & 363 & 287 & 237 \\
\hline $\begin{array}{c}\text { Kitzikapenen } \\
\text { uhin-luzera (nm) }\end{array}$ & 415 & 340 & 371 \\
\hline $\begin{array}{c}\text { Igorpenen } \\
\text { uhin-luzera (nm) }\end{array}$ & & \\
\hline
\end{tabular}


Aukeratutako hiru analitoak terapia kardiobaskularrean erabiltzen dira. Amilorida pirazinen familiako konposatu diuretiko bat da; bere izaera diuretikoa sodioaren absortzioaren inhibizioan oinarritzen da. Propranolola naftalenoen familiako beta blokeatzaile bat da; errezeptore adrenergikoak blokeatzen ditu eta bihotzaren aktibitatea jaisten du. Valsartana, ordea, tetrazolen oinarrizko egitura kimikoa duen konposatua da; Angiotensina IIren antagonista izanik, odol-hodien estutzearen kontra jokatzen du [21].

\subsection{Baldintza kromatografikoak}

Bereizketa kromatografikoa aurrera eramateko fase mugikor bezala $\%$ 0,01 azido formikoa duen ur-disoluzioa (A fasea) eta azetonitriloa (B fasea) erabili dira. Aplikatutako gradientea hurrengoa izan da: lehenengo, 0,5 minututan konposizioa konstante mantendu da $\% 1 \mathrm{~B}$ fasea erabiliz. Gero, B fasearen konposizioa linealki igo da 3. minutuan \% 99 izan arte. Konposizio hori konstante mantendu da 0,5 minutuz eta berriro hasierako konposiziora itzuli da (\% 1, B fasea). Sistema minutu bat egonkortzen utzi da hurrengo injekzioa egin aurretik. Fluxua $0,55 \mathrm{~mL} / \mathrm{min}$-koa izan da, zutabearen tenperatura $35{ }^{\circ} \mathrm{C}$ finkatu da eta laginak $10{ }^{\circ} \mathrm{C}$-tan mantendu dira. Injekzio bolumena $5 \mu \mathrm{L}-\mathrm{koa}$ izan da Pressure Assisted injekzio metodoa erabiliz [22]. Detekzioari dagokionez, absortzioa 190-400 nm-ko uhin-luzera tartean neurtu da eta fluoreszentziaren neurketa farmakoen kitzikapenen eta igorpenen uhin-luzerak $\left(\lambda_{\text {kitz }} / \lambda_{\text {ig }}\right)$ kontuan hartuz programatu da: 0,00-1,39 $\mathrm{min}, 363 / 415 \mathrm{~nm} ; 1,40-1,99 \mathrm{~min}, 287 / 340 \mathrm{~nm} ; 2,00-4,50$, $237 / 371 \mathrm{~nm}$.

\subsection{Erauzketaren optimizazioa}

Analitoen banaketan eragina izan dezaketen faktoreak ikasi baino lehen, haien analisia baimentzen duen laginaren tratamendua garatu da. Horretarako lehenengo urratsa OTLa erauzteko erabili den disoluzioaren konposizioa optimizatzea izan da, hau da, disolbatzaile organikoaren eta fase urtsuaren proportzioa eta fase urtsuaren $\mathrm{pH}$-a optimizatu dira. Optimizazio sistematikoari ekin aurretik egindako analisietan ikusi da azetonitriloa ez dela disolbatzaile organiko egokia analisia oztopatzen duten odoleko konposatu endogenoak erauzten dituelako. Beraz, metanola hautatu da disolbatzaile organiko bezala, betiere uraren proportzioa \% 30etik behera mantenduz, ur-proportzio handiago batekin beste konposatu endogenoak erauzten baitira. Metanolaren proportzio zehatzaren eta fase urtsuaren $\mathrm{pH}-$ aren optimizazioa dopatutako odol-tanta osoa hartuz burutu da, analizatu diren lagin guztiek beti analito kantitate berdina izan dutela ziurtatzeko. Ondoren, erauzlearen bolumena optimizatu da; kasu honetan zuloaren bidezko analisia burutu da hartutako laginaren azalerak bolumen egokia baldintzatzen duen ikusteko. Azkenik, ultrasoinuen edo irabiaketaren bidezko erauzketa gauzatuko den erabaki da. 


\subsubsection{Erauzketa-disoluzioaren $\mathrm{pH}$-aren optimizazioa}

$\mathrm{pH}$-ak farmakoen polaritatean izan dezakeen eragina kontuan izanda, erauzketan $\mathrm{pH}$-aren eragina aztertzea erabaki da. Horretarako, $100 \mathrm{mM}$ ko kontzentrazioa duten hainbat $\mathrm{pH}$-tako disoluzio indargetzaileak $(\mathrm{pH}-$ aren 2-12 bitarteko balioetakoak: 2, 4, 6, 8, 10 eta 12) prestatu dira. Ondoren, erauzketak egiterako mementoan, metanol:disoluzio indargetzailearen (75:25) $200 \mu \mathrm{L}$ erabilita, odol-tantak osotasunean erauzi dira, $\mathrm{pH}$ bakoitzeko hiru erreplika eginez.

Erauzketak pH ezberdinetan egitean nabarmendu da honek eragin handia duela analitoen berreskurapenetan. 2. irudian hiru analitoen azalera kromatografiko normalizatuak erakusten dira $\mathrm{pH}$ ezberdinetan (normalizazioa analito bakoitzaren kasuan, azalera maximoa eskaini duen $\mathrm{pH}$-aren azalerarekin egin da interpretazioa errazteko).

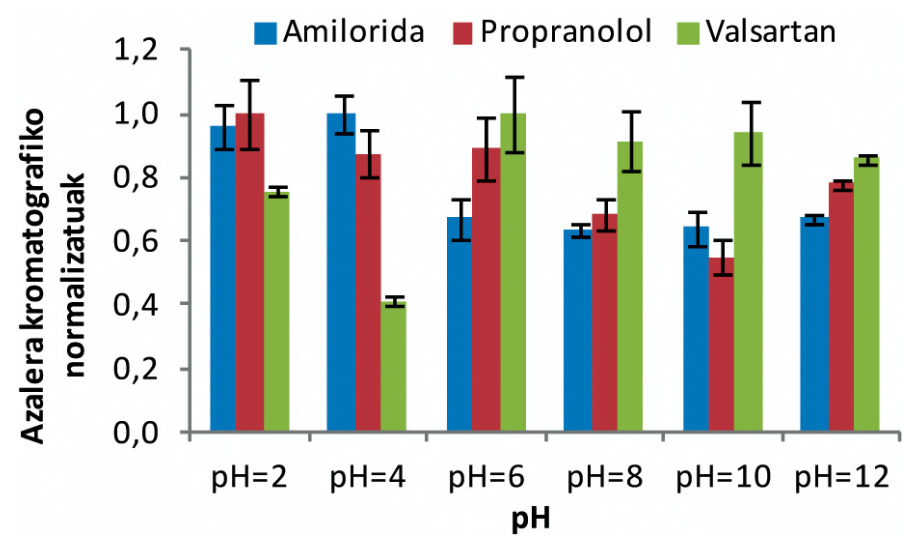

2. irudia. Analitoen azalera kromatografiko normalizatuen emaitzak $\mathrm{pH}$ ezberdineko disoluzio indargetzaileekin erauzi ondoren, metanol:disoluzio indargetzailearen (75:25) proportzioan.

Zenbat eta azidoagoa izan $\mathrm{pH}-\mathrm{a}$, orduan eta gehiago erauzten dira amilorida eta propranolola. Valsartanak, ordea, $\mathrm{pH}$ basikoagoetan seinale handiagoa erakusten du. Analitoen portaera hori molekulen polaritatearen igoerarekin bat dator, disolbatzaile polarra erabiltzean forma polarren erauzketa hobetzat hartzen bada. Amiloridaren berreskurapena $\mathrm{pH}=4$ tik gora jaisten da bere polaritatea bezala, bere bi talde nitrogenatuen desprotonazioa dela eta. Propranololak ere polaritate jaitsiera nabarmena dauka aminaren desprotonazioaren ondorioz, baina, $\mathrm{pH}=12$ inguruko polaritatea (eta berreskurapena) arinki igotzen da hidroxidoaren desprotonazioagatik. Valsartanak ordea, erauzketarik baxuena $\mathrm{pH}=4$ inguruan adierazten $\mathrm{du}$, espezie neutroa nagusia den tartean. 
Modu honetan eta hiru analitoen seinale maximoa lortzeko asmoarekin, erauzketa $\mathrm{pH}=2 \mathrm{ko}$ disoluzio indargetzailearekin $(100 \mathrm{mM}$, azido fosforiko/potasio fosfato) gauzatzea erabaki da.

Hain $\mathrm{pH}$ azidoarekin lan egiteak analitoen degradazioa eragin dezakeenez, farmakoen egonkortasuna aztertu da. Horretarako, $5 \mathrm{mg} / \mathrm{L}-\mathrm{ko}$ disoluzioak prestatu dira $\mathrm{pH}=2$ an eta prestatu bezain laster eta 3 egun pasa ondoren analizatu dira. Ez da gailur kromatografikoen azaleren ezberdintasunik antzeman, ezta degradazio produktuen agerpenik ere nabarmendu. Horrela, $\mathrm{pH}=2$ an analitoak degradatu gabe erauzketa gauzatu daitekeela ondorioztatu da.

\subsubsection{Erauzketa-disoluzioaren metanol-kantitatearen hautatzea}

Aurretik aipatu den bezala, metanolaren proportzio minimoa \% 70ean finkatu da konposatu endogenoen eluzioa ekiditeko. Proportzio optimoa bilatzeko, odol-tanta osoak $200 \mu \mathrm{L}$ disoluziorekin erauzi dira, metanol:disoluzio indargetzailearen $(\mathrm{pH}=2)$ proportzioak aldatuz $(70: 30,75: 25,80: 20$, 90:10, eta 100:0). Bakoitzeko hiru erreplika egin dira.

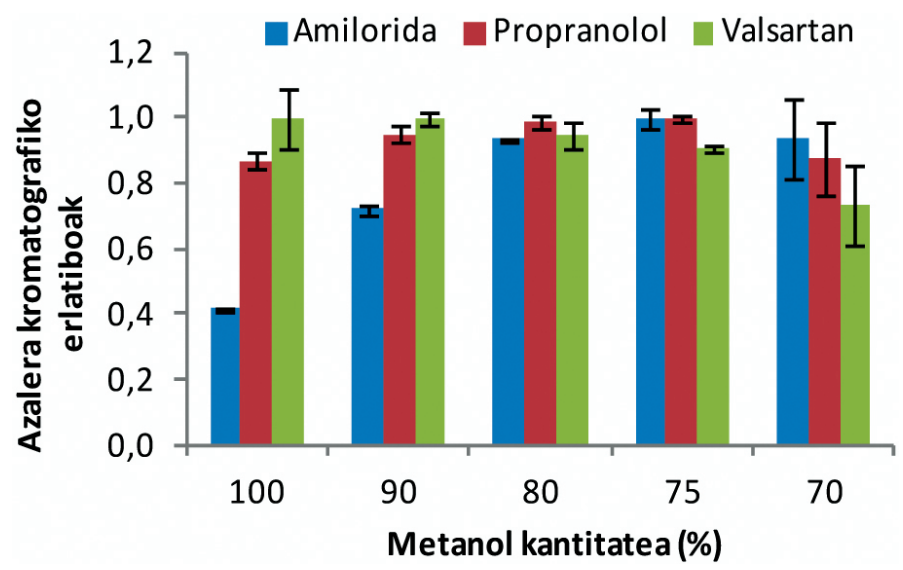

3. irudia. Analitoen azalera kromatografiko normalizatuen emaitzak metanol:disoluzio indargetzailearen $(\mathrm{pH}=2)$ proportzio ezberdinekin erauzi ondoren.

Disoluzio urtsu bezala $\mathrm{pH}=2 \mathrm{ko}$ disoluzio indargetzailea erabilita, metanolaren \% 70-\% 100 bitarteko kantitateetan egindako erauzketen emaitza normalizatuak 3. irudian ikus daitezke. Emaitza horiek erauzketa disoluzioaren polaritatearekin erlazionatuta dagoela baieztatzen dute. Jakina da uraren polaritatea metanolarena baino altuagoa dela, beraz, bi horien 
nahasteetan zenbat eta ur proportzioa altuagoa izan disoluzioa orduan eta polarragoa izango da. Modu horretan, esan daiteke polartasun-igoera horrek duela amiloridaren erauzketan (analito polarrena) eraginik handiena. Propranololaren eta valsartanaren azalerekin, ordea, ez da efektu hori sumatzen metanolarekiko afinitate handiagoa baitute.

Azalera maximoak metanol:ur (70:30) eta $(75: 25)$ proportzioak erakutsi arren, metanol:ur (70:30) proportzioak eskaintzen duen errepikakortasuna txarragoa da, ziur aski \% 30eko ur proportzioarekin oraindik lehen aipatu diren eta analisia oztopatzen duten konposatu endogenoetakoren bat erauzten delako. Beraz, proportzio optimoa metanol:ur (75:25) dela ondorioztatu da, azalera kromatografiko maximoak eta errepikakorrenak izan baitira.

\subsubsection{Erauzlearen bolumenaren hautatzea}

Orokorrean, OTLaren teknika aurrera eramateko erabilitako bolumena 100-350 $\mu$ L-ko tartean dago. Kontuan hartu behar da zenbat eta handiagoa izan bolumena, orduan eta erantzun baxuagoa edukiko dela analitoen diluzioagatik nahiz eta berreskurapena hobetu. Modu berean, bolumen txikiegia erabiltzean posible da disoluzioa asetzea eta berreskurapen baxua lortzea $[5,7,16,20]$. Horretan guztian oinarrituta 100-500 $\mu$ L-ko tartea aztertu da. $100 \mu \mathrm{L}-\mathrm{ko}, 150 \mu \mathrm{L}-\mathrm{ko}, 200 \mu \mathrm{L}-\mathrm{ko}, 250 \mu \mathrm{L}-\mathrm{ko}, 300 \mu \mathrm{L}-\mathrm{ko}$ eta $500 \mu \mathrm{L}$-ko erauzketa-bolumenak erabilita, odol-tantan egindako zuloak analizatu dira. Bakoitzeko hiru erreplika egin dira.

Frogatutako erauzketa bolumen-tarteetan ikusi da zenbat eta bolumen handiagoa erabili, orduan eta seinale baxuagoa lortzen dela analitoen diluzioaren ondorioz. Modu horretan, berreskurapen erlatiboak konparatu ahal izateko, bigarren aldiz normalizatu dira emaitzak bolumen erlazioak erabilita (adibidez, $500 \mu$ L-ri dagokion azalera bost aldiz handitu da $100 \mu$ L-koarekin konparatzeko). Lortutako emaitzetan oinarrituta (4. irudia) ikus daiteke amiloridaren eta propranololaren kasuetan ez dela erauzketa maximoa lortzen bolumen txikienetan. Valsartanak, ordea, ez du joera hori erakusten; honetan erauzketa konstante mantentzen da.

Emaitza horietan oinarrituta, erauzketan $200 \mu$ L-ko disoluzioa erabiltzea erabaki da. Berreskurapen handia lortzen delako sentikortasuna gehiegi gutxitu gabe eta laginaren tratamendu erosoa ahalbidetzen delako. Kontuan hartu behar da bolumen txikiekin zulatutako laginaren erauzketa eraginkorra bermatzea zailagoa dela eta ondorioz, laginaren tratamendua luzatzen dela. 


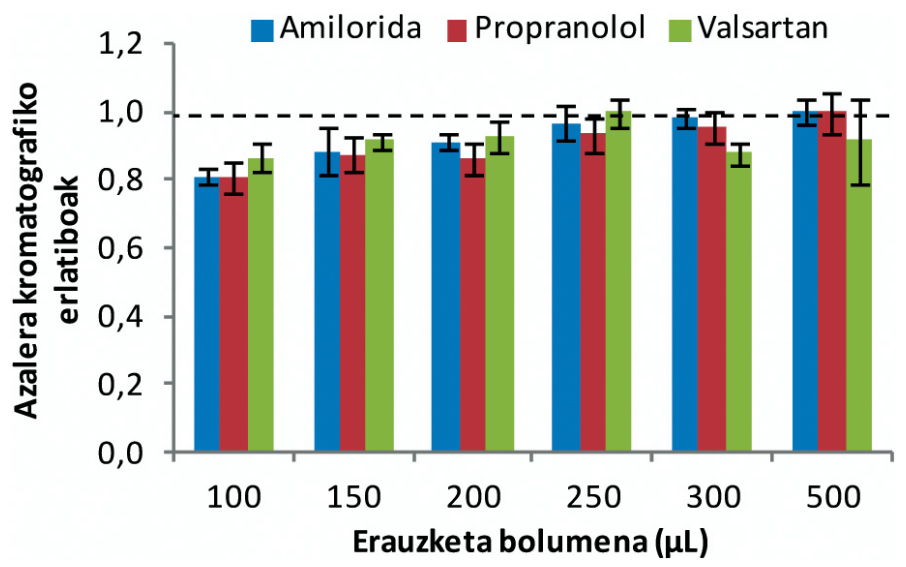

4. irudia. Analitoen azalera kromatografiko normalizatuen emaitzak, bolumen erlazioa kontuan hartuz, erauzketa bolumen ezberdinekin erauzi ondoren, metanol:disoluzio indargetzaile $(\mathrm{pH}=2)(75: 25)$ erabiliz. Puntu-lerroa lortutako berreskurapen maximoari dagokio.

\subsubsection{Erauzketa-sistemaren hautatzea}

Erauzketa aurrera eramateko, bi sistema konparatu dira, ultrasoinu-bainua eta irabiagailua (1.200 bira minutuko). Horretarako, OTLean egindako zuloak analizatu dira, $200 \mu \mathrm{L}$-ko erauzketa-disoluzioa erabiliz, metanol:disoluzio indargetzailearen $(\mathrm{pH}=2)(75: 25)$ proportzioan. Bakoitzeko hiru erreplika egin dira, erauzketa 20 minutuz egin da eta analizatu aurretik zentrifugatu da.

Emaitzetan oinarrituta sistema biak erabiltzean emaitza konparagarriak $\%$ 95eko konfiantza mailarekin lortzen direla ondorioztatu da. Hori horrela izanik, ultrasoinu-bainuarekin lan egitea erabaki da aldi berean lagin kopuru gehiagorekin lan egitea baimentzen duelako.

\subsection{Berreskurapenaren kalkulua}

Erauzketa prozesu baten berreskurapena kalkulatzeko, analizatuko den laginaren kontzentrazio zehatza jakitea beharrezkoa da. OTLaren kasuan zulatu den azaleran dagoen kontzentrazioa ezezaguna denez, berreskurapena kalkulatzeko modurik ohikoena tanta osoa erauztean datza, zuloa erauzteko erabiltzen den erauzketa-bolumen berdina erabiliz. Horrela erauziko den laginaren kontzentrazioa $(1 \mathrm{mg} / \mathrm{L})$ eta bolumena $(25 \mu \mathrm{L})$ ezagunak direnez, euskarrian dagoen analito kantitatea kalkulatu daiteke. Jakinda $200 \mu \mathrm{L}$ erabili direla erauzketa prozesuan, erauz- 
keta egin ostean disoluzioan egon daitekeen analito kontzentrazio maximoa kalkulatu da $(0,125 \mathrm{mg} / \mathrm{L})$. Lortutako erauzkina kontzentrazio hori duen disoluzio estandar batekin konparatuta berreskurapena kalkulatu da.

Nahiz eta azaldutako prozedura onartuena izan, posible da horrela metodoaren benetako berreskurapena ez lortzea. Orokorrean odol-bolumenaren eta erauzketa-disoluzioaren arteko erlazioa analisian erabiliko dena baino txikiagoa denez, berreskurapena txikiesten da (metodoan zuloa analizatzen da eta berreskurapena kalkulatzeko tanta osoa).

Hori kontuan hartuta, aurreko prozeduraren bidez analitoen berreskurapena txikiesten den aztertzeko tanta osoa erauzi da erauzketa-bolumena $500 \mu \mathrm{L}-$ ra arte handiagotuz. Erauzkin horren azken kontzentrazio teorikoa $0,05 \mathrm{mg} / \mathrm{L}$ dela kontuan hartuta, estandar batekin konparatu da berreskurapena kalkulatzeko eta aurreko prozedurarekin emaitzak aldaratzeko. Gero, jakinda ohiko analisietan zulatutako laginarekin lan egiten dela eta ez tanta osoarekin, berreskurapena kalkulatzeko prozedura berria proposatu da. Suposatuz analitoaren banaketa homogeneoa dela, tanta osoaren eta zuloaren arteko azaleren erlazioa kalkulatuz [20] zuloaren azalerari dagokion analito masa kalkulatu da, horretarako bost tanten osoen eta bost zuloen azalera erlazionatuz. Modu horretan zuloa analizatuz lortzen den erauzkinaren seinalea dagokion disoluzio estandarraren seinalearekin $(0,049 \mathrm{mg} / \mathrm{L})$ konparatuta berreskurapena kalkulatu da. Proposatutako hiru metodo horiek hiru odol-tantekin gauzatu dira; lortutako berreskurapenak 2. taulan bildu dira.

Tanta osoarekin burututako analisietan ikus daiteke $500 \mu \mathrm{L}-\mathrm{ko}$ erauzketa-bolumena erabiltzean, amiloridarentzat eta propranololarentzat berreskurapen balio altuagoak lortzen direla (2. taulan emaitzak ikus daitezke). Hau $200 \mu \mathrm{L}$ erabiltzean disoluzioa asetzen den seinale izan daiteke. Hori ikusita, orokorrean OTLaren berreskurapena kalkulatzeko erabilitako metodologiak analito batzuetan behintzat benetako berreskurapena ez duela eskainiko ondorioztatu da.

2. taula. Berreskurapenean lortutako emaitzen konfiantza tartea, tanta osoa bolumen ezberdinekin erauztean eta zuloa erauztean.

\begin{tabular}{lccc}
\hline \multicolumn{1}{c}{ Berreskurapena } & \multicolumn{2}{c}{ Tanta osoa (\%) } & Zuloa (\%) \\
\cline { 2 - 4 } Erauzketa bolumena & $200 \mu \mathrm{L}$ & $500 \mu \mathrm{L}$ & $200 \mu \mathrm{L}$ \\
\hline Amilorida & $60 \pm 2$ & $70 \pm 1$ & $95 \pm 3$ \\
Propranolola & $77 \pm 3$ & $88 \pm 2$ & $85 \pm 7$ \\
Valsartana & $65 \pm 4$ & $69 \pm 2$ & $67 \pm 3$ \\
\hline
\end{tabular}


Benetako berreskurapena kalkulatzeko asmoarekin analisia baldintza normaletan burutu denean, zuloaren eta tantaren arteko azalera erlazioak kontuan hartu dira. Propranololarentzat eta valsartanarentzat konparagarriak dira $500 \mu$ L-rekin erauzitako tanta osorako lortzen diren emaitzak, erauzketa eraginkorra den seinale. Amiloridarekin, ordea, berreskurapen nabarmenki altuagoa lortzen da. Kontuan izan behar da berreskurapena kalkulatzeko analitoen banaketa homogeneoa aurresuposatu dela. Gerta liteke amilorida tantan zehar homogeneoki ez dispertsatzea barnealdean kontzentratuz. Horrela, odol-tantaren zulaketa erdialdean egin denez, amilorida kantitatea altuagoa izan da eta horregatik espero izan den berreskurapena baino balio altuagoa lortu da. Hain zuzen ere, hau izan da analitoen banaketa heterogeneoaren lehenengo seinalea eta banaketa baldintzatzen duten faktoreen azterketan eragin duena.

\subsection{Hematokritoaren eta lagin-bolumenaren eraginaren azterketa OTLaren analisian}

Jakinda populazioaren hematokritoen balio arruntak \% 36-50 tartean daudela [23], ikerketa egin da hematokritoen balioen \% 25-55 bitarteko hurrengo mailak aztertuz: $\% 25, \% 30, \% 35, \% 40, \% 45, \% 50$ eta $\% 55$. Euskarrian gehitutako lagin-bolumenak ere analitoen dispertsioan eragina izan dezakeenez $[19,24]$, hematokrito maila bakoitzeko hiru bolumen ezberdin $(15 \mu \mathrm{L}, 25 \mu \mathrm{L}$ eta $35 \mu \mathrm{L})$ ikertu dira eta bakoitzeko hiru erreplika egin dira.

Bi aldagaietako ANOVA analisiaren bidez eta \% 95eko konfiantza mailarekin nabarmendu da, amiloridarentzat eta propranololarentzat hematokritoak eragina duela, lagin-bolumenak aldiz, ez. Valsartanaren kasuan bi aldagaiek eragin esanguratsua dutela ikusi da, hematokritoaren eragina askoz nabarmenagoa izanik.

Hematokritoak eragina izan duela ikusirik, aldagai hau bakarka sakonago ikasi da analito ezberdinentzat. Hematokritoak lortutako seinalean duen eragina argi ikus daiteke 5. irudian. Bertan propanololaren azalera kromatografikoa hematokrito balioarekin igotzen dela erakusten da. Analito guztientzat hiru bolumenetan, muturretako hematokrito balioen emaitzen artean ezberdintasunik dagoen aztertu da t frogaren bidez (\% 95eko konfiantza mailarekin). Orokorrean baieztatu da analitoaren erantzuna hematokritoaren ehunekoarekin batera igotzen dela. Horrek logikoa dirudi tantaren tamaina hematokritoarekin txikitzen dela kontuan hartuta; ondorioz, diametro berbereko zulo baterako analizatzen den odol kantitatea handiagoa da. 


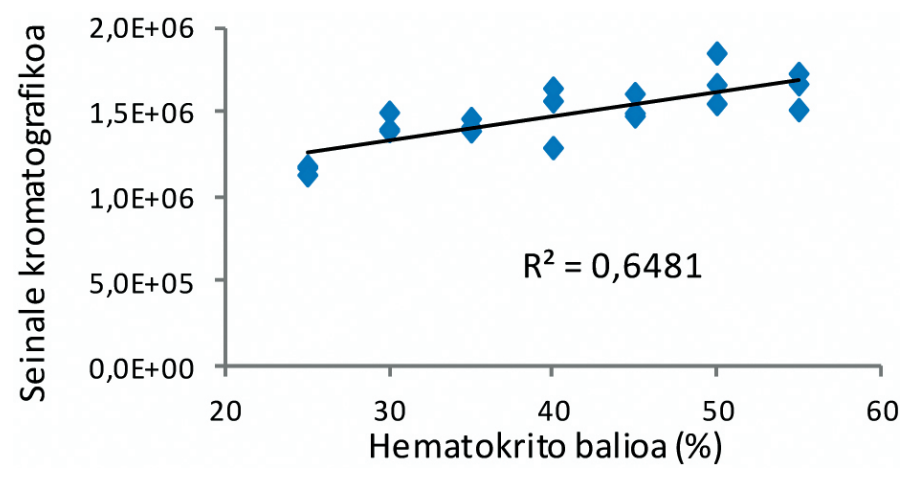

5. irudia. Hematokritoaren balio ezberdinetarako $15 \mu \mathrm{L}-\mathrm{ko}$ tantaren propranololaren analisien seinale kromatografikoak.

\subsection{Zuloaren kokapenaren eragina}

Erakutsi den bezala, analitoen dispertsioa heterogeneoa gerta daiteke odol-tantan zehar [15]. Alde batetik posible da hori gertatzea odola, berez, euskarrian homogeneoki ez delako banatu eta euskarriak malda txiki bat duelako (ikusi 1. irudia). Bestetik, egile batzuek ikusi duten bezala, analitoek euskarriarekiko eta odolarekiko duten afinitatearen ezberdintasuna dela eta, euskarrian zehar bereizketa kromatografikoa gerta daiteke [10]. Horren ondorioz, analito bakoitzak dispertsio ezberdina izan ahal du. Hori kontuan izanda, analizatutako zuloaren kokapenaren araberako emaitza kuantitatiboak asko alda daitezke.

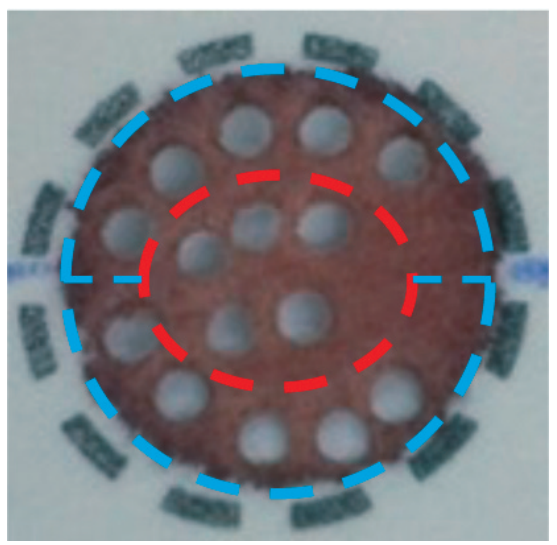

6. irudia. Odol-tantan zulatutako gune ezberdinak. Urdinez periferikoa (kanpoko goialdea eta kanpoko behealdea, banatuz) eta gorriz barnealdea. 
Analitoen dispertsioa aztertzeko odol-tantak hiru gunetan banatu dira goiko aldea, behekoa eta barnealdea; kasu honetan, gainera, odol-tantak zulatzeko 1,2 mm-ko diametroa duen zulagailua erabili da (guneak 6. irudian ikus daitekeen bezala banatu dira). Halaber, sentsibilitate arazoak ez edukitzeko kalkulatu da orain arte erabilitako zuloaren eta 1,2 mm-ko diametroa duen zuloaren azaleren arteko erlazioa. Modu horretan ondorioztatu da 17 zulo txiki behar direla antzeko intentsitate kromatografikoa lortzeko. Analisia egiteko, muturreko hematokritoaren balioak (\% 25 eta \% 55) dituzten odol-laginak erabili dira, bakoitzeko $35 \mu \mathrm{L}$-ko bederatzi tanta behar izan dira. Erreplika bakoitzeko 15 zulotxo erabili dira (5 zulotxo eginez hiru tanta ezberdinetan); hiru erreplika egin dira.

$\% 25$ eta \% 55 bitarteko hematokritoaren odol-laginen hiru gune ezberdinak (goiko aldea, beheko aldea eta barneko aldea) konparatu dira hiru farmakoentzat. Lortutako emaitza normalizatuak 7. irudian erakusten dira.

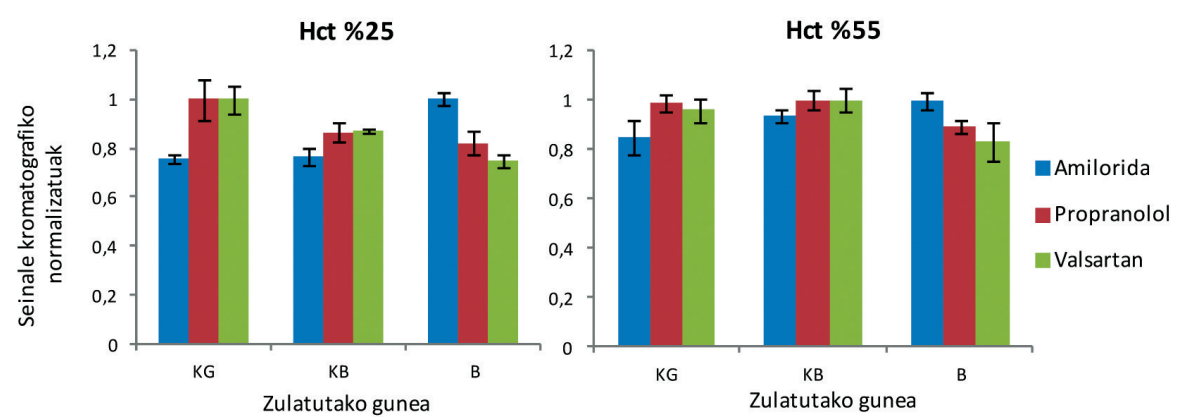

7. irudia. Odol-tantaren kanpoko eta barneko guneen konparaketaren analisiaren azalera kromatografiko normalizatuak $(\mathrm{KG}=$ kanpoko goialdea, $\mathrm{B}=$ barnealdea, $\mathrm{KB}=$ kanpoko behealdea).

Emaitzetan oinarrituz eta F froga aplikatuz \% 95eko konfiantza mailan, esan daiteke guneetan zehar bariantzaren ezberdintasun esanguratsurik ez dagoela, eta ondorioz, errepikakortasuna konparagarria dela odol-tantaren gune ezberdinetan. Ondoren, t froga egitean (\% 95eko konfiantza mailan), bi joera ezberdin ikusi dira ikertutako analitoetan. Alde batetik, amiloridak kontzentrazio altuagoa erakutsi du OTLaren gune zentralean, ezberdintasun hau hematokrito baxuko analisietan nabarmenagoa izanik. Bestetik, propanololaren eta valsartanaren dispertsioa guztiz kontrakoa izan da; ikusi da gune periferikoan azaltzen duten kontzentrazioa barnealdekoa baino altuagoa dela.

Modu horretan, jokaera hori bibliografian aurkitutako informazioarekin bat datorrela ikusi da, non bi dispertsio posible proposatu diren: gune 
zentraletik periferikorantz kontzentrazioaren jaitsiera nabarmentzea (amilorida) edo alde periferikoan kontzentrazio altuagoa azaltzea, sumendiefektua deritzona (propranolola eta valsartana). Egile batzuek portaera hau euskarriarekiko afinitatearen ondorioa dela defendatzen dute [10, 15]. Horren arabera, gerta daiteke amilorida analito polarrena izanda euskarriarekin elkarrekintza sendoagoak sortzea eta, ondorioz, gutxiago dispertsatzea (paper-kromatografian gertatuko litzatekeen moduan).

\section{ONDORIOAK}

Lan honetan, OTLaren laginketa-teknikak farmakoen analisi kuantitatibora aplikatzerako orduan hainbat ahulgune dituela baieztatu da. Alde batetik frogatu da analito kontzentrazio berbera baina hematokritoaren balio ezberdina duten laginek seinale ezberdina eskaintzen dutela. Portaera hori odol-tantaren azalera ezberdintasunarekin lotu da. Beste alde batetik, ikusi da analitoen dispertsio heterogeneoa dela eta, analisia gauzatzeko zuloaren kokapena funtsezko aldagaia dela analisi kuantitatiboaren ikuspuntutik. Gainera, dispertsio hori ezberdina (eta aurresanezina) denez analitoaren arabera, konposatu anitzen aldibereko analisia gauzatzeko oztopo handia bihurtzen da.

Arazo horiek saihesteko, zuloaren bidezko analisia burutu ordez odoltanta osoa analizatzea aukera bat izan daiteke, modu horretan euskarrian ipini den tantan dagoen analito kantitate osoa hartuko bailitzateke. Hala ere, modu horretan kontzentrazioa kalkulatzeko ipinitako odol-tantaren bolumena ezagutzea ezinbestekoa da. Argi dago hori ez dela arazoa mikropipeten bidez laborategian prestatutako laginentzat, baina izugarri zailduko luke laginketa bolumena neurtu gabe euskarrian ipintzen denean, hala nola ospitaleetako jaioberrien laginak hartzean edo 3. munduko biztanleen odola eskuratu nahi denean. Beraz, laginketa egiteko erraztasuna izanik OTLaren teknikaren abantaila garrantzitsuenetarikoa ezin da baztertu zuloen bidezko analisia eta arretaz aztertu behar da metodo kuantitatibo fidagarriagoak garatzeko helburuarekin.

\section{ESKER ONAK}

Egileek Ekonomia eta Lehiakortasun Ministerioaren (CTQ 201346179-R proiektua), Euskal Herriko Unibertsitatearen (UFI 11/23) eta Eusko Jaurlaritzaren (IT 789/13 proiektua) diru-laguntzak eskertu nahi dituzte. Era berean, Basurtuko Unibertsitate Ospitaleko hematologiako zerbitzuari eskerrak eman nahi dizkiote odol-laginen hornikuntzagatik. 


\section{BIBLIOGRAFIA}

[1] DEMIREV, P.A. 2013. «Dried blood spots: analysis and applications». Analytical chemistry, 85(2), 779-89.

[2] ODOARDI, S., ANZILLOTTI, L. and STRANO-ROSSI, S. 2014. «Simplifying sample pretreatment: application of dried blood spot (DBS) method to blood samples, including postmortem, for UHPLC-MS/MS analysis of drugs of abuse». Forensic science international, 243, 61-7.

[3] LI, W. and TSE, F.L. 2010. «Dried blood spot sampling in combination with LC-MS/MS for quantitative analysis of small molecules». Biomedical chromatography: BMC, 24(1), 49-65.

[4] TRETZEL, L., THOMAS, A., GEYER, H., GMEINER, G., FORSDAHL, G., POP, V., SCHANZER, W . and THEVIS, M. 2014. «Use of dried blood spots in doping control analysis of anabolic steroid esters». Journal of pharmaceutical and biomedical analysis, 96, 21-30.

[5] BERM, E.J., PAARDEKOOPER, J., BRUMMEL-MULDER, E., HAK, E., WILFFERT, B. and MARING, J.G. 2015. «A simple dried blood spot method for therapeutic drug monitoring of the tricyclic antidepressants amitriptyline, nortriptyline, imipramine, clomipramine, and their active metabolites using LC-MS/MS». Talanta, 134, 165-72.

[6] HAWWA, A.F., ALBAWAB, A., ROONEY, M., WEDDERBURN, L.R., BERESFORD, M.W. and MCELNAY, J.C. 2014. «A novel dried blood spot-LCMS method for the quantification of methotrexate polyglutamates as a potential marker for methotrexate use in children». PloS one, 9(2), e89908.

[7] CVAN TROBEC, K., TRONTELJ, J., SPRINGER, J., LAINSCAK, M. and KEREC KOS, M. 2014. «Liquid chromatography-tandem mass spectrometry method for simultaneous quantification of bisoprolol, ramiprilat, propranolol and midazolam in rat dried blood spots». Journal of chromatography. B, Analytical technologies in the biomedical and life sciences, 958, 29-35.

[8] VILLANELLI, F., GIOCALIERE, E., MALVAGIA, S., ROSATI, A., FORNI, G., FUNGHINI, S., SHOKRY, E., OMBRONE, D., DELLA BONA, M.L., GUERRINI, R. and LA MARCA, G. 2015. «Dried blood spot assay for the quantification of phenytoin using Liquid ChromatographyMass Spectrometry». Clinica chimica acta; international journal of clinical chemistry, 440, 31-5.

[9] COX, H.D., RAMPTON, J. and EICHNER, D. 2013. «Quantification of insulin-like growth factor-1 in dried blood spots for detection of growth hormone abuse in sport». Analytical and bioanalytical chemistry, 405(6), 1949-58.

[10] LI, W. and LEE, M.S. 2014. Dried Blood Spots: Applications and Techniques. Wiley.

[11] DEGLON, J., THOMAS, A., MANGIN, P. and STAUB, C. 2012. «Direct analysis of dried blood spots coupled with mass spectrometry: concepts and biomedical applications». Analytical and bioanalytical chemistry, 402(8), 2485-98. 
Odol Tanta Lehorraren fidagarritasunaren azterketa farmakoen analisi kuantitatiborako UHPLC-PDA-FLDren bidez

[12] EDELBROEK, P.M., VAN DER HEIJDEN, J. and STOLK, L.M. 2009. «Dried blood spot methods in therapeutic drug monitoring: methods, assays, and pitfalls». Therapeutic drug monitoring, 31(3), 327-36.

[13] DE KESEL, P.M., CAPIAU, S., LAMBERT, W.E. and STOVE, C.P. 2014. «Current strategies for coping with the hematocrit problem in dried blood spot analysis». Bioanalysis, 6(14), 1871-4.

[14] CAPIAU, S., STOVE, V.V., LAMBERT, W.E. and STOVE, C.P. 2013. «Prediction of the hematocrit of dried blood spots via potassium measurement on a routine clinical chemistry analyzer». Analytical chemistry, 85(1), 404-10.

[15] COBB, Z., DE VRIES, R., SPOONER, N., WILLIAMS, S., STAELENS, L., DOIG, M., BROADHURST, R., BARFIELD, M., VAN DE MERBEL, N., SCHMID, B., SIETHOFF, C., ORTIZ, J., VERHEIJ, E., VAN BAAR, B., WHITE, S. and TIMMERMAN, P. 2013. «In-depth study of homogeneity in DBS using two different techniques: results from the EBF DBS-microsampling consortium». Bioanalysis, 5(17), 2161-9.

[16] SVENSSON, L.D., SENNBRO, C.J., SVANSTROM, C. and HANSSON, G.P. 2015. «Applying dried blood spot sampling with LCMS quantification in the clinical development phase of tasquinimod». Bioanalysis, 7(2), 17991.

[17] WILHELM, A.J., DEN BURGER, J.C., VOS, R.M., CHAHBOUNI, A. and SINJEWEL, A. 2009. «Analysis of cyclosporin A in dried blood spots using liquid chromatography tandem mass spectrometry». Journal of chromatography. $B$, Analytical technologies in the biomedical and life sciences, 877(14-15), 1595-8.

[18] LI, Y., HENION, J., ABBOTT, R. and WANG, P. 2012. «The use of a membrane filtration device to form dried plasma spots for the quantitative determination of guanfacine in whole blood». Rapid communications in mass spectrometry : RCM, 26(10), 1208-12.

[19] TER HEINE, R., ROSING, H., VAN GORP, E.C., MULDER, J.W., VAN DER STEEG, W.A., BEIJNEN, J.H. and HUITEMA, A.D. 2008. «Quantification of protease inhibitors and non-nucleoside reverse transcriptase inhibitors in dried blood spots by liquid chromatography-triple quadrupole mass spectrometry». Journal of chromatography. B, Analytical technologies in the biomedical and life sciences, 867(2), 205-12.

[20] VU, D.H., KOSTER, R.A., ALFFENAAR, J.W., BROUWERS, J.R. and UGES, D.R. 2011. «Determination of moxifloxacin in dried blood spots using LC-MS/MS and the impact of the hematocrit and blood volume». Journal of chromatography. B, Analytical technologies in the biomedical and life sciences, 879(15-16), 1063-70.

[21] DrugBank [Kontsultatua: 10/07/2015]; Erabilgarri: http://www.drugbank. $\mathrm{ca} /$.

[22] WIKLUND, T. Acquity UPLC Injection Technigues Fixed Loop and Flow through Needle [Kontsultatua: 13/07/2015]; Erabilgarri: https://www.waters. 
com/webassets/cms/library/docs/local_seminar_presentations/DA_ NUT2013_G4_Tony_Wiklund.pdf.

[23] BACELLS, A. 1989. La clinica y el laboratorio. Salvat.

[24] DAMEN, C.W., ROSING, H., SCHELLENS, J.H. and BEIJNEN, J.H. 2009. «Application of dried blood spots combined with high-performance liquid chromatography coupled with electrospray ionisation tandem mass spectrometry for simultaneous quantification of vincristine and actinomycin-D». Analytical and bioanalytical chemistry, 394(4), 1171-82. 